\title{
Desain dan implementasi sistem penjadwalan agenda berbasis android
}

\author{
Rahmah $^{1}$, Mansur ${ }^{2}$ \\ ${ }^{1,2}$ Program Studi Teknik Informatika Jurusan Teknik Informatika Politeknik Negeri Bengkalis \\ Jln. Bhatin Alam Sungai Alam, Bengkalis, Riau, Telp. (+62766) 7008877 \\ e-mail: ${ }^{1}$ rahmahh03@gmail.com, ${ }^{2}$ mansur.polbeng82@gmail.com
}

\begin{abstract}
Abstrak
Penjadwalan agenda merupakan sebuah proses pembuatan urutan rencana kerja kedalam bentuk daftar catatan yang berisi kegiatan sehari-hari dari seorang individu. Saat ini, penggunaan teknologi Android sudah berkembang pesat diberbagai bidang kehidupan, seperti halnya penerapan aplikasi pengingat yang dibuat untuk menjadwalkan agenda. Meskipun alarm pengingat jadwal agenda telah berbunyi, tetap saja sebagian orang sering mengabaikan hal tersebut dan mematikan alarmnya dengan menekan salah satu tombol. Penelitian ini bertujuan untuk mendesain dan mengimplementasi sistem penjadwalan agenda berbasis Android yang akan mempermudah setiap individu dalam menjadwal agenda kegiatan seharihari. Aplikasi ini dibuat menggunakan bahasa pemrograman Java, Web Service, Eclipse dan database MySQL. Hasil penelitian ini berupa desain sistem yang dapat diimplementasikan untuk sistem penjadwalan agenda dengan fitur menambah agenda pribadi, kontak, pengiriman agenda, serta menampilkan alert dialog berisi informasi tentang jadwal agenda kegiatan yang harus dikerjakan dan bunyi alarm harus direspons pengguna. Berdasarkan pengujian yang dilakukan, aplikasi ini dapat berjalan pada berbagai versi Android mulai dari versi 4.2.2 hingga 6.0.1.
\end{abstract}

Kata Kunci: Agenda, Desain, Implementasi, Penjadwalan.

\begin{abstract}
Scheduling agenda is a process of making sequences work plan into the form of a list of records that contain the daily activities of an individual. Currently, the use of the Android technology already growing rapidly in various areas of life, as with any application of the reminder application made to schedule agenda. Although the alarm reminder schedule agenda has been read. Nonetheless, some people often overlook it and turn off the alarm by pressing any key. This research aims to design and implement of agenda scheduling system based android that will make it easier to every individual in the schedule of daily activities agenda. This application is created using the Java programming language, Web services, Eclipse and MySQL database. The results of this research in the form of system design that can be implemented for agenda scheduling system with features to add the personal agenda, contacts, sending the agenda, as well as displaying alert dialog contains information about the schedule of the activities agenda should be done and the sound of the alarm should respond to users. based on the testing done, this application can run on a variety of Android version starting from version 4.2.2 to 6.0.1.
\end{abstract}

Keywords: Agenda, Design, Implementation, Scheduling. 


\section{Pendahuluan}

Perangkat mobile yang menggunakan teknologi Android sudah berkembang pesat diberbagai bidang kehidupan, seperti halnya agenda yang biasa dicatat pada media kertas dapat dibuat kedalam media elektronik seperti perangkat mobile. Aplikasi reminder merupakan salah satu teknologi Android yang dibuat untuk penjadwalan agenda. Aplikasi reminder merupakan personal asistant untuk mencatat segala aktivitas atau pertemuan yang dilengkapi dengan fitur yang dapat sangat membantu dari pengguna aplikasi [1].

Melihat kondisi saat ini, alarm dikira masih belum berpengaruh terhadap sebagian individu. Hal yang tidak asing lagi kita dengar, yaitu ketika alarm dijadikan sebagai pengingat untuk waktu sahur, bangun tidur dan pengingat waktu sholat. Meskipun alarm telah berbunyi tetap saja sebagian orang sering mengabaikan hal tersebut dan mematikan alarmnya, yang mana alarm tersebut akan langsung mati dengan menekan salah satu tombol. Selain itu, bagi orangtua yang sibuk bekerja, terkadang tidak sempat mengawasi dan mengatur langsung jadwal seharihari anaknya seperti jadwal untuk waktu ibadah dan belajar dirumah. Dalam dunia pendidikan juga terdapat masalah dengan pengaturan jadwal, seperti mahasiswa kadang-kadang sering lupa dengan jadwal rapat, jadwal bertemu dosen pembimbing dan pergantian jadwal mata kuliah yang sudah ditetapkan.

Telah banyak penelitian yang membahas tentang aplikasi pengingat agenda pribadi seperti pada referensi [1], dalam artikel berjudul Pemodelan Aplikasi Mobile Reminder Berbasis Android, membahas tentang aplikasi pengingat pada perangkat mobile dengan menggunakan Android OS, Google Maps, Google Cloud Messaging, Web Service serta menggunakan database SQLite dan MySQL. Tujuan penelitian ini adalah untuk mengatasi kelalaian dan kemalasan masyarakat. Aplikasi ini membantu pengguna yang membutuhkan bantuan untuk dapat mengatur jadwal aktivitas dengan baik.

Berdasarkan permasalahan tersebut, diperlukan suatu pengembangan aplikasi reminder, yaitu berupa desain dan implementasi sistem penjadwalan agenda berbasis Android guna mempermudah setiap individu seperti mahasiswa dan orangtua untuk menjadwal setiap agenda kegiatan. Aplikasi penjadwalan untuk manajemen agenda berbasis Android merupakan aplikasi pengingat yang dilengkapi dengan beberapa fitur seperti fitur tambah kontak, fitur input agenda pribadi dan fitur pengiriman agenda. Pada fitur pengiriman agenda, pengguna aplikasi dapat mengirim jadwal agenda kesesama pengguna aplikasi yang sama. Agenda yang dikirim akan langsung masuk ke aplikasi Android pengguna yang dituju. Kelebihan aplikasi ini adalah bunyi alarm akan berhenti setelah penggunanya meng-input kata kunci yang berupa teks pada kotak alert dialog yang ditampilkan. Aplikasi ini dibuat menggunakan teknologi Android, Web Service dan software yang digunakan meliputi Eclipse dengan bahasa pemrograman Java dan database yang digunakan yaitu MySQL. Aplikasi ini menghasilkan informasi tentang jadwal agenda kegiatan yang harus dijalani dan diharapkan mampu mengurangi tingkat keterlambatan, meningkatkan kedisiplinan waktu dan mendorong setiap individu agar bisa lebih baik lagi dalam memanajemen waktu.

\section{Tinjauan Pustaka}

\section{a. Desain dan Implementasi Sistem}

Perancangan merupakan langkah pertama dalam fase pengembangan rekayasa produk atau sistem. Fase ini adalah inti teknis dari proses rekayasa perangkat lunak. Pada fase ini elemenelemen dari model analisa dikonversikan. Dengan menggunakan satu dari sejumlah metode perancangan, fase perancangan akan menghasilkan perancangan data, perancangan antar muka, perancangan sistem dan perancangan prosedur [2]. Desain sistem bertujuan untuk memenuhi kebutuhan kepada para pemakai, serta memberikan gambaran yang jelas dan rancang bangun yang lengkap dari sistem aplikasi yang akan dibangun [3].

Implementasi atau penerapan merupakan tahap dimana desain sistem dibentuk menjadi suatu kode (program) yang siap untuk dioperasikan [4]. 


\section{b. Penjadwalan (Timetabling)}

Jadwal adalah pembagian waktu berdasarkan rencana pengaturan urutan kerja, daftar atau rencana kegiatan dengan pembagian waktu pelaksanaan yang lebih detail. Penjadwalan memiliki arti proses pembuatan jadwal atau memasukkan recana kegiatan ke dalam jadwal [5].

Penjadwalan merupakan suatu alokasi, berfokus pada constraints, dan resource untuk object yang ditempatkan pada ruang dan waktu untuk memenuhi sedekat mungkin seperangkat tujuan yang diinginkan [6]. Penjadwalan yang baik akan memaksimalkan pemanfaatan setiap sumber daya yang ada dalam suatu kegiatan operasi, sehingga penjadwalan merupakan kegiatan penting dalam perencanaan dan pengendalian proses. Tahap perencanaan dan tahap implementasi dari kegiatan penjadwalan termasuk masalah manajemen waktu yang kompleks [7].

c. Android

Android merupakan sistem operasi yang dikembangkan untuk perangkat mobile berbasis Linux. Android menyediakan platform terbuka bagi para pengembang untuk menciptakan aplikasi mereka sendiri untuk digunakan oleh bermacam peranti bergerak [8].

\section{d. Eclipse}

Eclipse adalah sebuah IDE (Integrated Development Environment) untuk mengembangkan perangkat lunak dan dapat dijalankan di semua platform Java [9]. Beberapa sifat yang dimiliki Eclipse, yaitu :

1. Multi-platform. Target sistem operasi Eclipse adalah Microsoft Windows, Linux, Solaris, $A I X, H P-U X$ dan juga Mac $O S X$.

2. Multi-role. Selain sebagai IDE untuk pengembangan aplikasi, Eclipse juga bisa digunakan untuk aktivitas dalam siklus pengembangan perangkat lunak, seperti dokumentasi, test perangkat lunak, pengembangan web dan lain sebagainya.

3. Multi-language. Eclipse dikembangkan dengan bahasa pemrograman Java, akan tetapi Eclipse mendukung pengembangan aplikasi berbasis bahasa perograman lainnya, seperti $\mathrm{C} / \mathrm{C}++$, Perl, $\mathrm{PHP}$ dan lain sebagainya.

Java merupakan sebuah bahasa pemrograman yang dapat dijalankan diberbagai komputer termasuk telepon seluler. Bahasa ini banyak mengadopsi sintaksis yang terdapat pada $\mathrm{C}$ dan $\mathrm{C}++$, namun dengan sintaksis model objek yang lebih sederhana serta mendukung rutin (user program) pada tingkat dasar. Java memperkenalkan diri sebagai bahasa pemrograman yang mendukung konsep Object Oriented Programming (OOP) secara total [10].

\section{e. MySQL (My Structured Query Language)}

MySQL merupakan media tempat penyimpanan data-data yang nantinya akan diperlukan oleh sistem dari aplikasi yang akan dibangun. MySQL adalah DBMS yang didistribusikan secara gratis lisensinya dari General Public License (GPL), dimana setiap orang bebas untuk menggunakannya tetapi tidak boleh untuk dijadikan program induk turunan bersifat close source (komersial). MySQL sebenarnya merupakan turunan dari salah satu konsep utama dalam basis data sejak lama, yaitu SQL (Structured Query Language). MySQL bersifat gratis atau open source sehingga kita bisa menggunakannya secara gratis. Pemrograman PHP juga mendukung atau support dengan database MySQL [11].

\section{f. Web Service}

Web service dibangun untuk memungkinkan aplikasi web untuk saling bekerja sama. Dengan Web Service, aplikasi web dapat mempublikasikan fungsi-fungsinya ke seluruh dunia. Salah satu prinsip Representational State Transfer (REST) web service, yaitu bertukar data dengan menggunakan XML, Java Script Object Notation (JSON) atau keduanya [4]. Web service dapat diartikan juga sebuah metode pertukaran data, tanpa memperhatikan dimana sebuah database ditanamkan, Sehingga web service mampu menjadi sebuah jembatan penghubung antara berbagai sistem yang ada [1]. 


\section{g. Agenda}

Agenda merupakan daftar catatan yang berisi kegiatan dari seorang individu. Agenda kegiatan biasanya dicatat pada sebuah buku. Salah satu fungsi agenda yaitu sebagai pengingat, sehingga dapat dibuka kembali jika sewaktu-waktu terlupa [1].

\section{h. Pengingat (Reminder)}

Reminder merupakan sebuah pesan yang menolong seseorang untuk mengingat sesuatu. Reminder dapat digunakan sebagai manajemen waktu yang berfungsi untuk memberi alarm peringatan berupa pemberitahuan berbasis lokasi, waktu maupun catatan yang berupa kontekstual [9].

\section{Metode Penelitian}

Dalam penelitian ini digunakan tahapan-tahapan yang dilakukan untuk memastikan upaya penelitian dan perancangan aplikasi akan mencapai hasil yang maksimal.

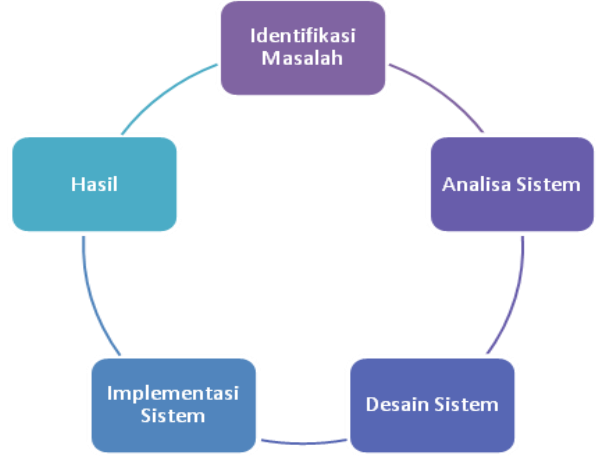

\subsection{Analisa Sistem}

Gambar 1. Prosedur penelitian

Analisa sistem diperlukan untuk mengetahui bagaimana kinerja dari aplikasi pengingat yang berjalan, yaitu pengguna meng-input jadwal agenda kegiatan pada aplikasi pengingat. Selanjutnya, alarm akan berbunyi sesuai dengan waktu yang sudah ditentukan pengguna. Bunyi tersebut akan berhenti setelah beberapa saat atau ketika pengguna menekan salah satu tombol. Sedangkan, aplikasi pengingat yang diusulkan adalah sistem penjadwalan agenda berbasis Android, dapat dilihat pada Gambar 2.

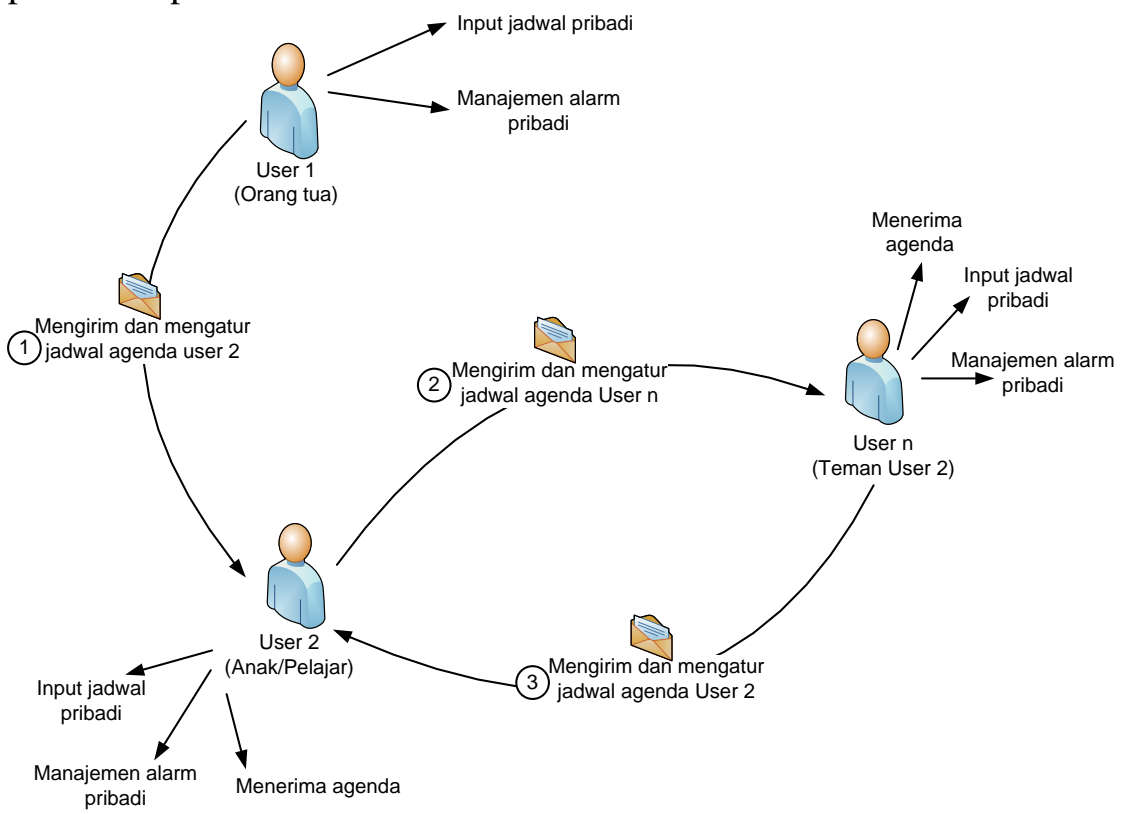

Gambar 2. Desain sistem aplikasi penjadwalan agenda yang diusulkan 
Gambar 2 menjelaskan tentang aplikasi penjadwalan yang akan dibangun. Masing-masing pengguna aplikasi pengingat ini dapat meng-input dan mengatur agenda pribadi. Selain itu, juga bisa mengatur agenda untuk pengguna lain. Orangtua dapat mengatur dan mengirim jadwal agenda ke anak, kemudian alarm di Android anak akan berbunyi sesuai dengan jadwal yang sudah dikirim orangtua. Pemilik aplikasi alarm ini juga bisa saling berkirim jadwal agenda kesesama pengguna yang memiliki aplikasi pengingat yang sama.

\subsection{Desain Sistem}

\section{Use Case Diagram}

Use case diagram menggambarkan hubungan antar actor dan tindakan apa yang dapat dilakukan oleh actor terhadap aplikasi [12]. Use case diagram sistem penjadwalan agenda dapat dilihat pada Gambar 3.

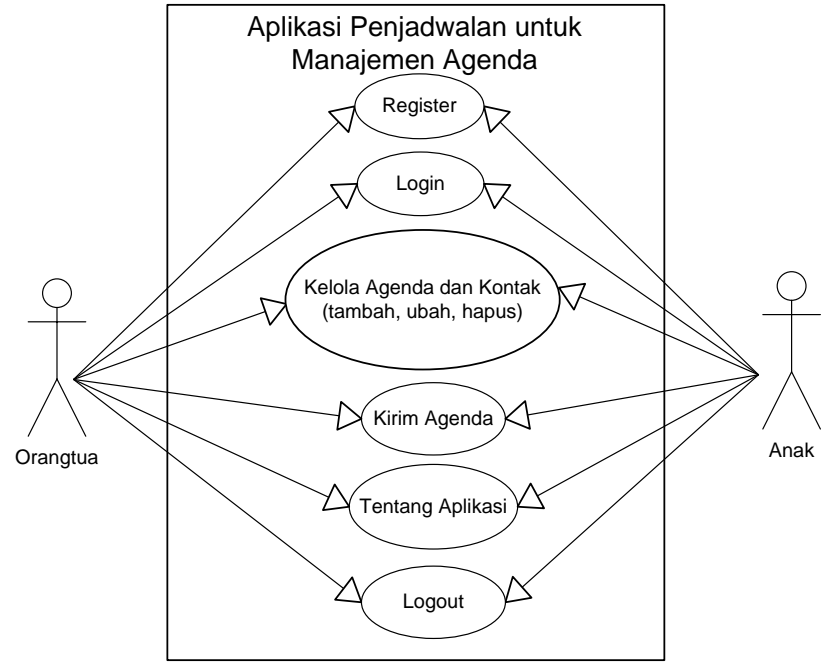

Gambar 3. Use case diagram

\section{Activity Diagram}

Activity diagram menggambarkan berbagai alir aktivitas sistem yang sedang dirancang. Terdapat beberapa activity diagram pada sistem penjadwalan agenda, yaitu activity diagram login, kelola agenda dan kontak, serta kirim agenda.

a. Activity Diagram Login dan Kirim

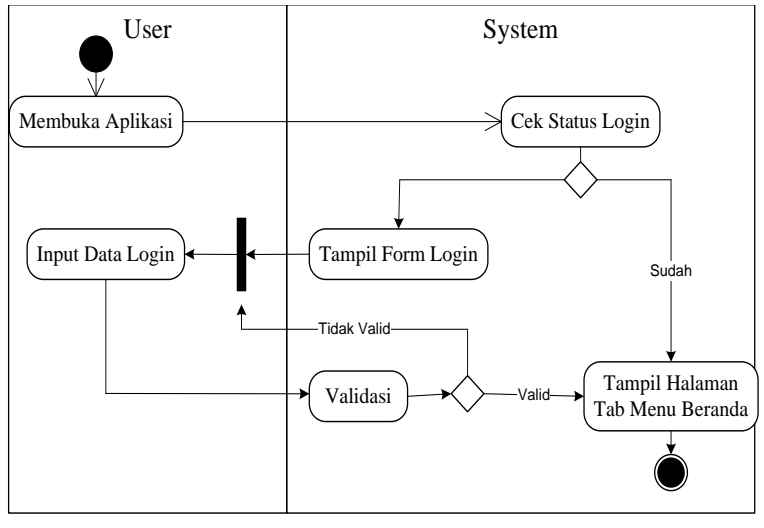

Gambar 4. Activity diagram login

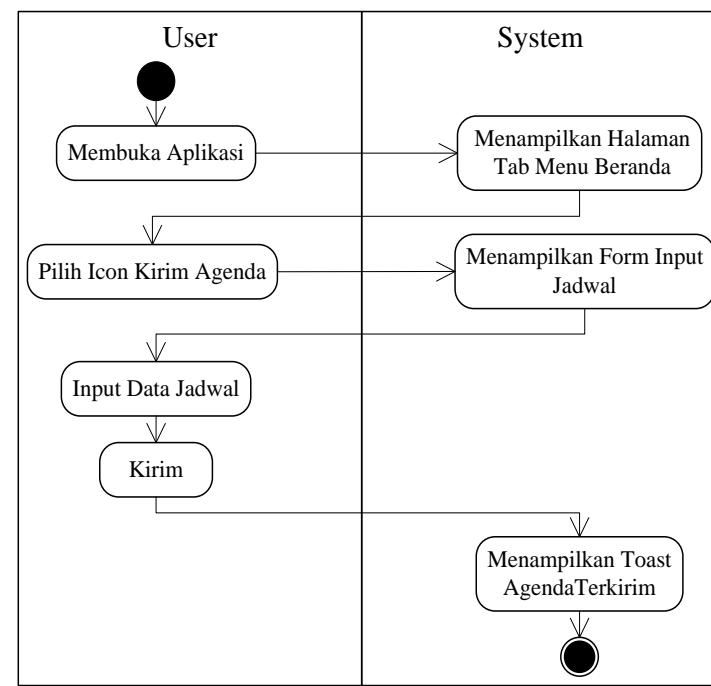

Gambar 5. Activity diagram kirim 
b. Activity Diagram Kelola Agenda dan Kontak

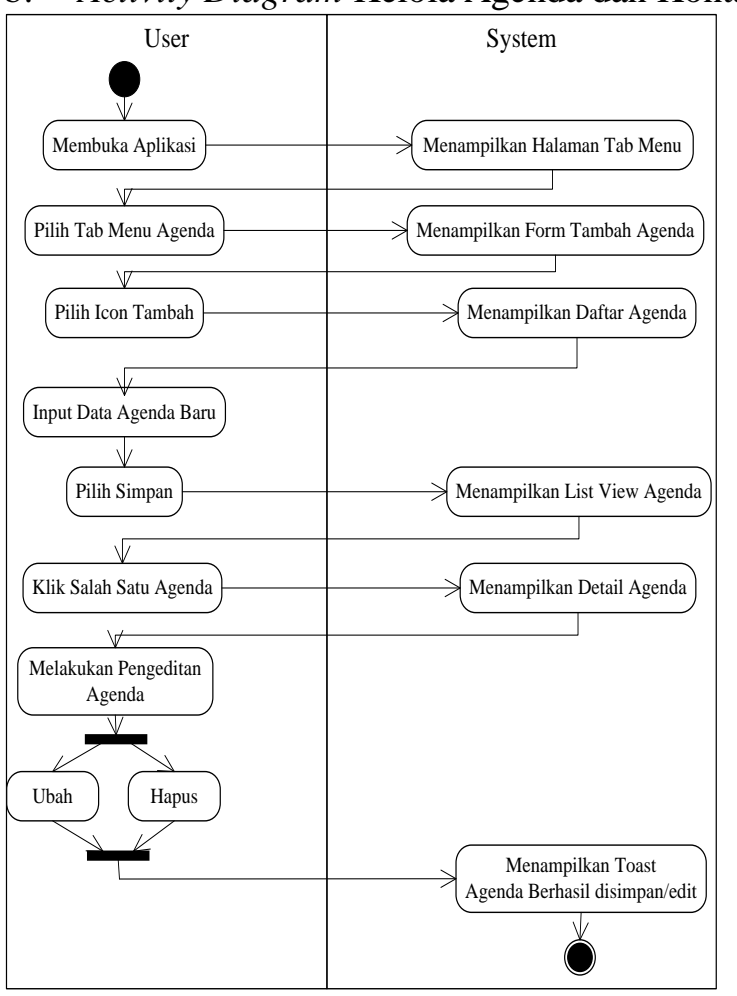

Gambar 6. Activity diagram kelola agenda pribadi

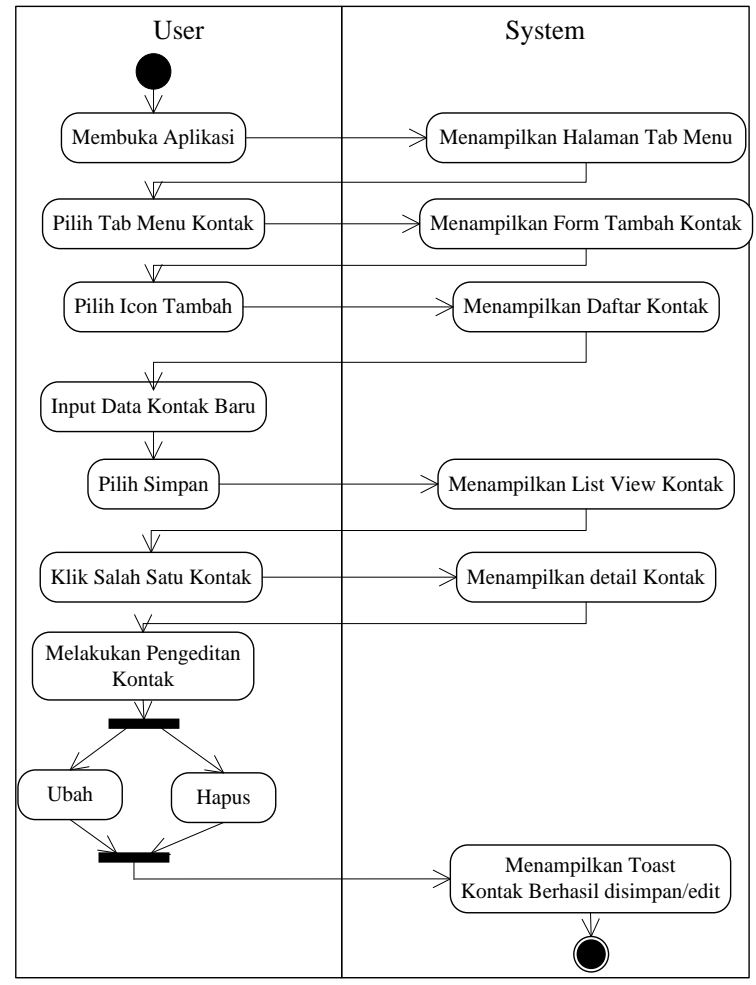

Gambar 7. Activity diagram kelola kontak

\section{User Interface}

User interface merupakan tampilan antarmuka aplikasi yang akan dilihat pengguna ketika menjalankan aplikasi. Berikut rancangan interface untuk aplikasi penjadwalan agenda yang dirancang.

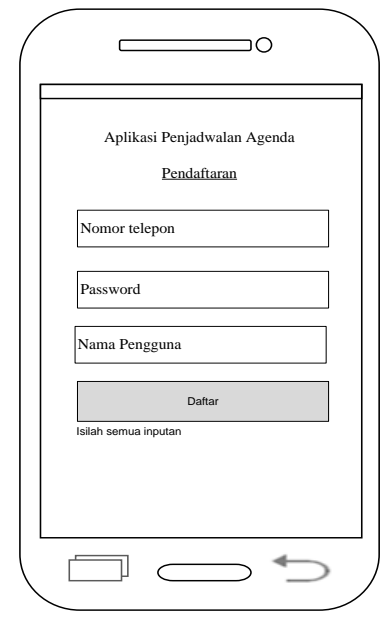

Gambar 8. Tampilan daftar

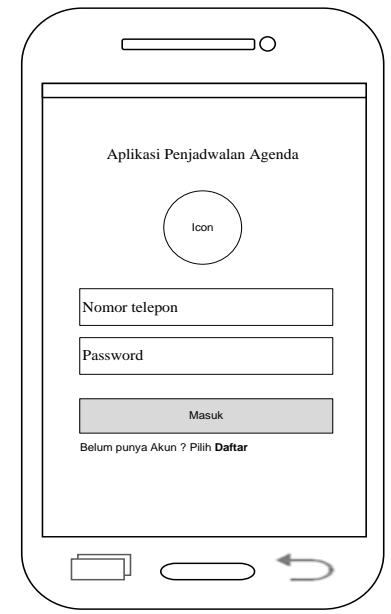

Gambar 9. Tampilan login 


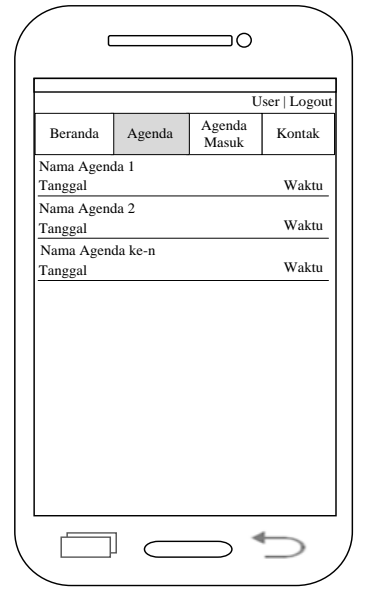

Gambar 10. Tampilan daftar agenda pribadi

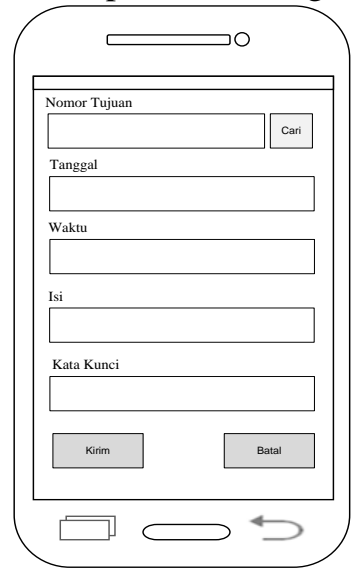

Gambar 12. Form kirim agenda

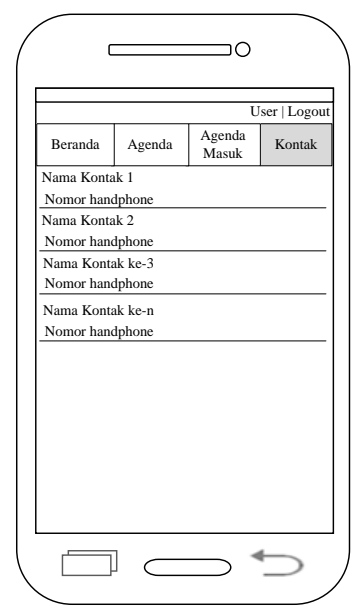

Gambar 11. Tampilan daftar kontak

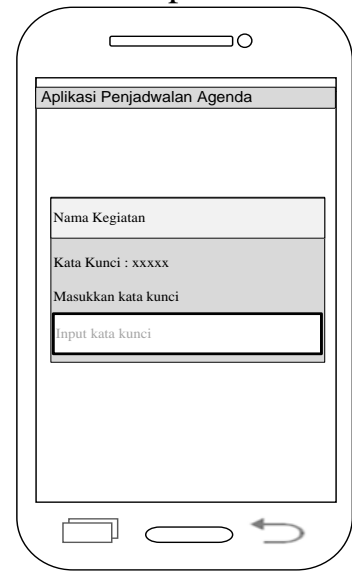

Gambar 13. Tampilan alert dialog

\section{Desain Database}

a. Entity Relationship Diagram (ERD)

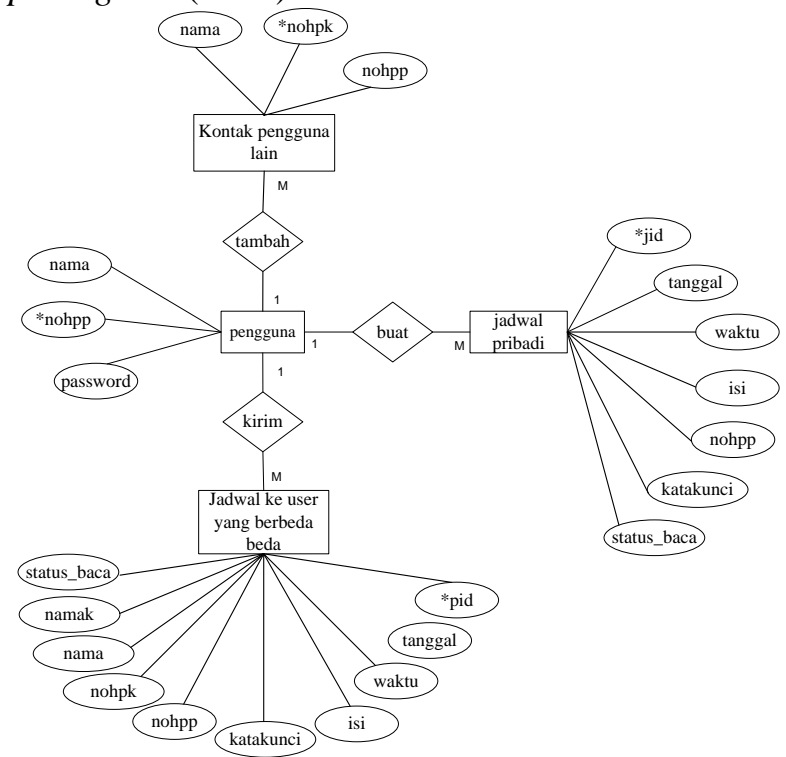

Gambar 14. Entity relationship diagram 
b. ERD Logikal

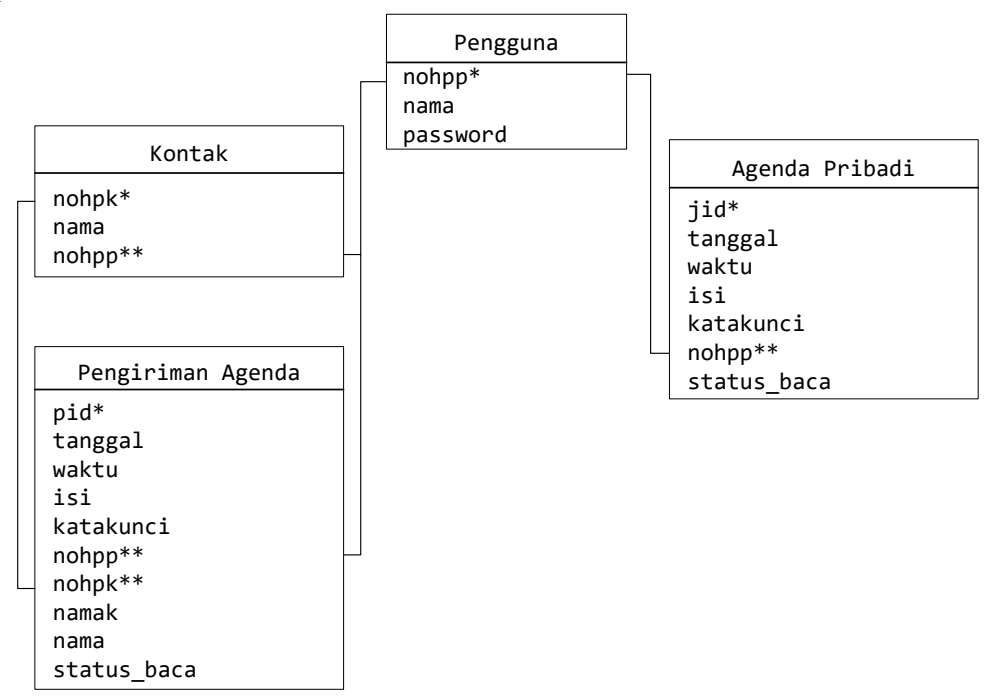

Gambar 15. Database logical

c. ERD Fisikal

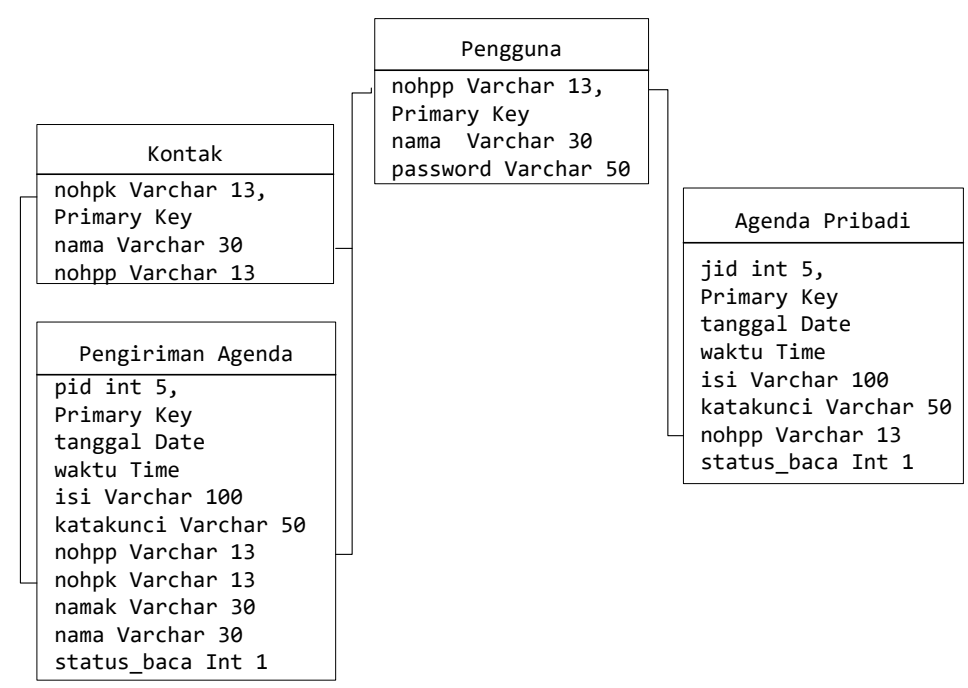

Gambar 16. Database fisikal

\section{Hasil dan Pembahasan}

Penelitian ini menghasilkan sistem penjadwalan agenda berbasis Android yang akan menampilkan informasi tentang jadwal agenda kegiatan yang akan dikerjakan. Pada aplikasi ini, terdapat fitur tambah kontak untuk mempermudah pengguna dalam proses pengiriman agenda. Fitur agenda pribadi dapat digunakan untuk menjadwal dan mengelola agenda pribadi serta terdapat juga fitur pengiriman agenda yang dapat digunakan untuk mengirim jadwal agenda ke user lain, dengan syarat harus menggunakan aplikasi yang sama. Aplikasi ini dibuat menggunakan bahasa pemrograman Java, Web Service, Eclipse dan database MySQL. Berikut hasil tampilan antarmuka yang terdapat pada aplikasi. 


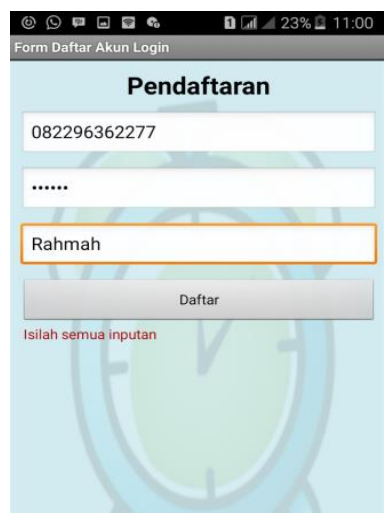

Gambar 17. Tampilan daftar

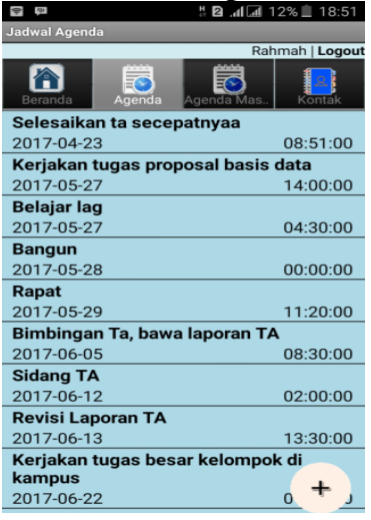

Gambar 19. Tampilan daftar agenda pribadi

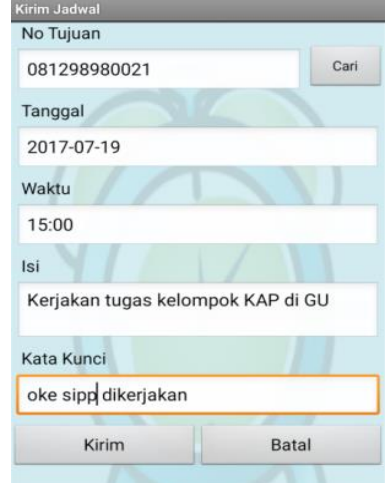

Gambar 21. Form kirim agenda

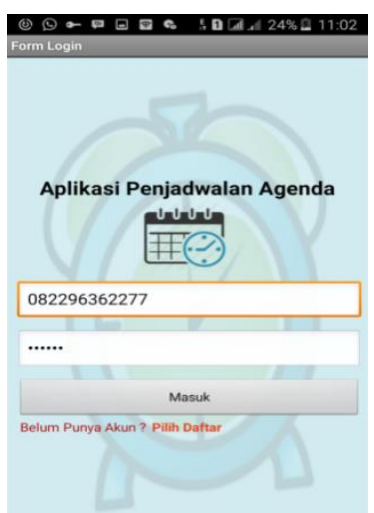

Gambar 18. Tampilan login

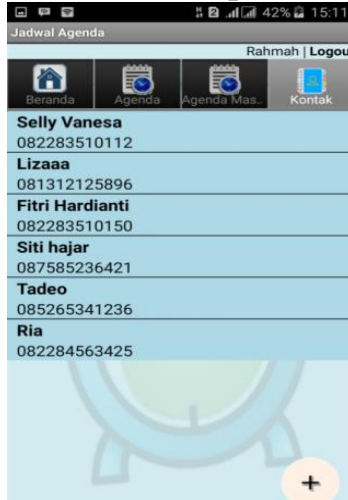

Gambar 20. Tampilan daftar kontak

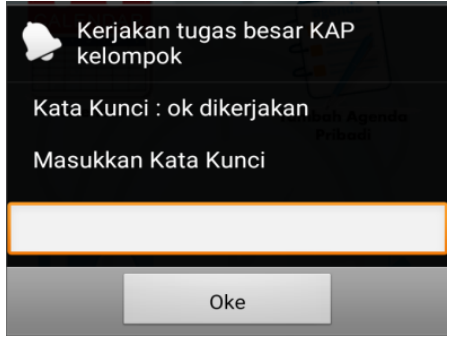

Gambar 22. Tampilan alert dialog

Tahap berikutnya yaitu implementasi sistem yang bertujuan untuk melakukan uji coba pada sistem yang sudah dibuat.

\section{a. Pengujian Fungsionalitas Aplikasi}

Tabel 1. Pengujian fungsionalitas aplikasi

\begin{tabular}{|c|c|c|c|}
\hline \multirow{2}{*}{ No } & Item Pengujian & \multicolumn{2}{|c|}{ Hasil } \\
\cline { 3 - 4 } & Splash Screen & $\checkmark$ & - \\
\hline 1 & Daftar dan Login & $\checkmark$ & - \\
\hline 2 & & & Gagal \\
\hline
\end{tabular}




\begin{tabular}{|c|c|c|c|}
\hline 3 & $\begin{array}{c}\text { Kelola Agenda } \\
\text { (tambah, ubah, hapus) }\end{array}$ & $\checkmark$ & - \\
\hline 4 & $\begin{array}{c}\text { Kelola Kontak } \\
\text { (tambah, ubah, hapus) }\end{array}$ & $\checkmark$ & - \\
\hline 5 & Kirim Agenda & $\checkmark$ & - \\
\hline 6 & Menu Tentang Aplikasi & $\checkmark$ & - \\
\hline 7 & Menu Keluar & $\checkmark$ & - \\
\hline 8 & Alert Dialog Alarm Berbunyi & $\checkmark$ & - \\
\hline
\end{tabular}

\section{b. Pengujian Berdasarkan Versi Sistem Operasi Android}

Tabel 2. Pengujian berdasarkan versi sistem operasi android

\begin{tabular}{|c|c|c|l|}
\hline No & Platform & Layar & \multicolumn{1}{c|}{ Hasil Pengujian } \\
\hline 1 & $\begin{array}{c}\text { Android } \\
4.2 .2 \\
\text { (Jelly } \\
\text { Bean })\end{array}$ & 6 inch & $\begin{array}{l}\text { Tampilan responsive, aktifitas kelola agenda (tambah, ubah, } \\
\text { hapus), kirim jadwal agenda ke user lain, alert dialog alarm } \\
\text { berbunyi sesuai dengan waktu dan tanggal yang telah diatur, dan } \\
\text { bunyi alarm mati setelah di input kata kunci, berhasil. }\end{array}$ \\
\hline 2 & $\begin{array}{c}\text { Android } \\
4.4 .4 \\
(\text { Kitkat })\end{array}$ & 4 inch & $\begin{array}{l}\text { Tampilan responsive, aktifitas kelola agenda (tambah, ubah, } \\
\text { hapus), kirim jadwal agenda ke user lain, alert dialog alarm } \\
\text { berbunyi sesuai dengan waktu dan tanggal yang telah diatur, dan } \\
\text { bunyi alarm mati setelah di input kata kunci, berhasil. }\end{array}$ \\
\hline 4 & $\begin{array}{c}\text { Android } \\
5.1 .1\end{array}$ & 5 inch & $\begin{array}{l}\text { Tampilan responsive, aktifitas kelola agenda (tambah, ubah, } \\
\text { hapus), kirim jadwal agenda ke user lain, alert dialog alarm } \\
\text { berbunyi sesuai dengan waktu dan tanggal yang telah diatur, dan } \\
\text { bunyi alarm mati setelah di input kata kunci, berhasil. }\end{array}$ \\
\hline 5 & $\begin{array}{c}\text { Android } \\
6.0 .1 \\
\text { (Marshma } \\
\text { llow })\end{array}$ & 5 inch & $\begin{array}{l}\text { Tampilan responsive, aktifitas kelola agenda (tambah, ubah, } \\
\text { hapus), kirim jadwal agenda ke user lain, alert dialog alarm } \\
\text { berbunyi sesuai dengan waktu dan tanggal yang telah diatur, dan } \\
\text { bunyi alarm mati setelah di input kata kunci, berhasil. }\end{array}$ \\
\hline
\end{tabular}

\section{Kesimpulan}

Berdasarkan hasil implementasi, dapat disimpulkan bahwa aplikasi ini dapat menjadwalkan setiap agenda kegiatan yang akan dilakukan pengguna. Bunyi alarm akan mati setelah pengguna meng-input kata kunci pada kotak alert dialog yang ditampilkan. Pemilik aplikasi pengingat ini juga bisa saling berkirim jadwal agenda ke sesama pengguna aplikasi yang sama. Hasil keluaran yang diperoleh dari aplikasi ini berupa alert dialog yang berisi informasi tentang jadwal agenda kegiatan yang harus dikerjakan. Aplikasi ini dapat berjalan dengan baik pada smartphone Android mulai dari versi 4.2.2 (Jelly Bean) hingga versi 6.0.1 (Marshmallow).

Dari kesimpulan yang telah dilihat, dapat dikemukan beberapa saran demi pengembangan yang lebih baik, yaitu:

1. Aplikasi penjadwalan agenda berbasis android sebaiknya dapat digunakan secara offline.

2. Pengiriman agenda sebaiknya dapat dikirim kebanyak user dalam waktu yang bersamaan. 


\section{Daftar Pustaka}

[1] Purwanto, D.D. (2014) Aplikasi Reminder pada Android Mobile Device, Jurnal Sistem Informasi, Sekolah Tinggi Teknik Surabaya, 20 (1), ISSN : 1858-4667.

[2] Mandolang, A. (2017) Rancang Bangun Aplikasi Agenda Kegiatan Pimpinan (Studi Kasus: Rektorat Unsrat), E-journal Teknik Informatika, 11 (1), ISSN : 2301-8304.

[3] Hidayat, T., Mansur, Rahmah. (2017) Desain Prototipe Aplikasi Sistem Monitoring Browser Ponsel Anak Untuk Menerapkan Internet Sehat Dengan Kontrol Orang Tua, Jurnal Teknologi Informasi \& Komunikasi Digital Zone, 8 (1), 43-49.

[4] Ramadhan, T., dan Utomo, V.G. (2014) Rancang Bangun Aplikasi Mobile untuk Notifikasi Jadwal Kuliah Berbasis Android (Studi Kasus : STMIK Provinsi Semarang), Jurnal Teknologi Informasi dan Komunikasi, 5 (2), ISSN : 2087-0868.

[5] Abdurahman, M. (2016) Sistem Informasi Jadwal Perkuliahan Berbasis Web Mobile Pada Politeknik Sains dan Teknologi Wiratama Maluku Utara, Indonesia Journal on Networking and Security, 5 (2), ISSN : 2302-5700.

[6] Mansur. (2015) Sistem Informasi Manajemen Penjadwalan Kuliah Menggunakan Pendekatan Integer Programming, Jurnal Ilmu Komputer, 1 (1), ISSN : 2442-4512.

[7] Syarif, A.C., dan Gunawan, F. H. (2013) Penerapan Algoritma Evolusi Dengan Metode Generation Replacement Pada Aplikasi Penjadwalan Mata Kuliah (Studi Kasus: Universitas Atma Jaya Makassar), Jurnal Tematika, 1 (2), ISSN : 23033878.

[8] Hermawan, S.S. (2011) Mudah Membuat Aplikasi Android, ANDI Yogyakarta.

[9] Kosidin dan Farizah, R.N. (2016) Pemodelan Aplikasi Reminder Berbasis Android, Seminar Nasional Teknologi Informasi dan Komunikasi 2016 (SENTIKA 2016), ISSN : 2089-9815.

[10] Syahril, D.S., Isnanto, R.R., dan Kridalukmana, R. (2016) Aplikasi Panduan Ibadah Haji Berbasis Android, Jurnal Teknologi dan Sistem Informasi, 4(3), ISSN : 2338-0403.

[11] Anhar. (2010) Panduan Menguasai PHP dan MySQL Database Server, Mediakita.

[12] Dara, Y., Kurniadi, D., dan Budayawan, K. (2014) Perancangan Aplikasi Perhitungan Zakat Mal, Menentukan Waktu Sholat dan Arah Kiblat Menggunakan GPS Berbasis Android, Jurnal Vokasional Teknik Elektronika \& Informatika, 2 (2), ISSN : 2302-3295. 